\title{
MEALINESS DETECTION IN APPLES USING TIME RESOLVED REFLECTANCE SPECTROSCOPY
}

\author{
C. VALERO . P. BARREIRO , M. RUIZ-ALTISENT, R. CUBEDDU, \\ A. PJHFERI , P. TARONI, A. TORRJCLLLJ, G. VALENTINI, D. JOHNSON \\ and $C$. DOVER
}
Department Ingenieria Kural, E.T.S.I. Agrónomos
Universidad Politétnicn Madrid
Avenida Complutense, 28040 Madrid
Spoin
INFM-Dipartimento di Fisica and IFN-CNR
Politemiro di Milano, Piazza
Leonardo da Vinci 32, 20133 Milan
taly

East Malling Rextarch

East Malling, Kent. MEI96RJ

U.K.

\begin{abstract}
Mealiness is a textural anribute related to internal fruit disorder that is characterized by the combination of abnormal soffness of the fruit and absence of free juiciness in the mouth when eaten by the consumer. Timerexolved laser reffectance spectroscopy was used as a tool to determine mealiness. This new lechnique in agrofood research may provide physical and chemical information independently and simultaneously. which is relevant to characterize mealiness. Using visible and near infrared lasers as light sources, time-resolved laser refleckance spectrossopy was applied in Colden Delicious and Cox apples $(\mathrm{n}=90)$. to characterize batches of untreared samples and samples that were stored under conditions that promote the development of mealiness ( $20 \mathrm{C} \& 95 \% \mathrm{RH})$. The collected database was clustered into different groups according to their instrumental test values. The optical coffficients were used as explanatory variahles to build discriminant functions for mealiness. The performance of the classification models created ranged from 47 to $100 \%$ of correctly identified mealy versus nonmealy apples.
\end{abstract}




\section{KEYWORDS}

Apple, laser reflectance spectroscopy, mealiness, near infrared spectroscopy, time-resolved spectroscopy, visible spectroscopy

\section{INTRODUCTION}

Consumers' decision at purchase is affected holh hy external aspect and internal quality of fruits. Among the quality parameters that a consumer can find in apples, mealiness is a main issue. It has been defined as a negative attribute of sensory texture thal combines the feeling of disaggregated tissue with lack of juiciness. It is a conseguence of a biochemical process resulting in pectin degradation in the middle lamellae (Gross and Sams 1984; Von Mollendor $e t$ al. 1993), and their consequences are visible by microscopic observalion (De Sinedt et al. 1998). Mealiness is associated with late harvest and long-lerm storage (Fisher 1943; Harker and Haliet1 1992). Mealiness onset may also be acceleraled hy temperature treatments (Von Mollendorf es al. 1992) combined with extremely high relative humidity (De Smed1 2000).

The characterisation of mealiness has been done traditionally by means of sensory panels defining and grading sensorial descriptors (Bignami $e t$ al. 2003). However, relations belween physiology changes, fruit texture and sensory measurements of tissue strength and juiciness have been estathlished success[ully (Paoletti et al. 1993; Harker et al. 1997; Verlinden et al. 1997). Correlations of sensory attributes (crispness and juiciness. at first bite and during chewing) to a combination of parameters measured using instrumental tests (contined compression of probes) have been establislred. Within the same work (Barreiro et al. 1998) a redefinition of mealiness in apples and peaches in terms of theological properties was proposed lollowing sensory descriptors in mealiness perception. A new instruntental mealiness scale was created, hased on a combination of insirumental parameters like loss of crispness, of hardness and of juiciness, which is able to characterize objectively the mealiness state of a given sample and correlates well with sensory mealiness (Barreiro et al. 1998). More sludies can be found also relaling to peaches (Sonego et al. 1995; Ortiz et al. 1999) and tomatoes (Ahrens and Huber 1987).

Several nondestructive methods for instrumental mealiness measurement of peaches, apples and tomatoes have been allempled using different techniques: near infrared speciroseopy (NIR) spectroscopy combined wilh low mass impac1 (Ortiz et al. 2001), acoustic impulse response (De Smed1 2000), ultrasonic wave propagation through fruil 1issues (Bechar et al. 2005) and nuclear magnetic resonance (NMR) (Barreiro et al. 1999). Nevertheless, the 
development of stand-alone nondestructive techniques is still needed, especially if they are fast and if they could be engincered into an aulomatic on-line classitication system (Abbott 1999).

Time-resolved reffectance spectroscopy (TRS) is a nonconventional spectroscopic technique that has been developed for use in medicine (Cubeddu et al. 1994a) to characterize the optical properties of tissues, and to locale discontinuilies and aflected areas like hum an and animal tumors. Among its advantages conipared with more traditional spectroscopic techniques, there is the reasibility to derive simuitaneously 1 wo (in principle) independent optical parameters: the absorption of the light inside the irradiated hody, and the scattering of the photons across the tissue. For each wavelength. TRS generates two coefficients $\left(\mu_{\mathrm{a}}\right.$, absorption cokfficient; and $\mu_{\mathrm{s}}^{\prime}$ transport scaltering coefficient). Both are dependent on wavelength. By measuring at consecutive wavelengths two arrays of values, an absorption spectrum and a "scattering spectrum," can be ohtained. The working bypothesis of the present work was that these cofficients are related, respectively, to chemical components $\left(\mu_{j}\right)$ and to physical properties $\left(\mu_{s}^{\prime}\right)$ of the sample. Therefore, TRS can be applied to the quantification of chemicals and the measurement of the rheolngical properlies (or the combination of hoth: soft texlure and dryness, i.e., mealiness) at the same time. TRS has been applied satisfactorily for the nondestruclive evaluation of fruil internal quality (Valero of al. 2004a,b). Using 490 apples from different varieties, links were found between the optical properties of the samples and their quality altributes obtained with standard procedures; statistical models were developed for the quantification of several aspects of liuit quality (fimness estimation, sugar content and acidity). In the present work, the objective was to apply TRS as a nondestruclive inspection method for mealiness.

\section{MATERIALS AND METHODS}

\section{Fruit Material}

Two groups of samples were prepared:

(1) Apples with expected "natural mealiness." In order to enhanced the risk of mealiness or abnormal lexlure degradation, apples were harvested late in the season: 50 Golden Delicious apples were picked from two orchards (La Almunia de Doña Godina, Zaragoza, Spain) during the lası week of October 1998 (late harvest), packed and sent to Milano (INFM) in November. Both firm and soft fruits were picked, in order to obtain all possible texural sates. About half of the samples were expected to be mealy as a consequence of developing mealiness on the tree. 
(2) Apples with mealiness induced in chamber siorage. In this case colleagues at the Catholic Universily of Leuven (Belgium) prepared al ong the autumn samples lrom the Cox variety, harvested early in the season (end of Septemher) and stofed until Novemher 1998 under sperific conditions: 20 of them were kept inside an ULO chamber (ultra low oxygen) to preserve their freshness at maximum levels; and 20 apples were kep1 during 16 days in an atmosphere of $95 \%$ relative humidity and $20 \mathrm{C}$, to promote the development of mealiness (Andani ot al. 1999). Nol all ol them were expected to be finally mealy in terms of instrumental mealiness. as indicated by previous sludies (Barreiro et al. 1998).

The reference tests (firmness and juiciness) and TRS measurements that were carried out on the samples are presented within in the same sequence as for the tests.

\section{TRS Measurements}

Time-resolved reflectance spectroscopy is based on the measurement of the broadening of a short light pulse, transmitted across a turbid medium ([ruit tissues) (Cubeddu ef at. 1994b). The TRS equipment used in this work is described in detail in the sludy by Cubeddu et al. (200) a.b). A simplified schemc of it is shown in Fig. I. The light source is a laser heam, therefore monochromatic, but tunable at several wavelengths. The light is injected in the fruit through the intact skin by means of fiber optics positioned orthogonal to the equator of the fruit. The light flux crosses the tissues and part of it finds its way out of the sample at a particular region adjacent to the injection point. This portion of reffected light was recovered with another fiber placed at $20 \mathrm{~mm}$ distance ( $\Gamma$ ig. 2). The optical paths of the photons with larger protability of being recovered alter sulfering internal reflection form a three-dimensional light region wilh a semitoroidal shape inside the apple, constructed from the incoming fiber contact point to the recovering fiber contact point on the skin. If an adequate theorelical model is used for the experimental aralysis of data and several hypolheses are eslablished, it is possible to calculate a1 the same time the absorption coefficient $\left(\mu_{i}\right)$ and the transport scattering cocfficient $\left(\mu^{\prime}\right)$ at each wavelength (Cubeddu ef al. 1994al. In our case, the diffusion theory (Eq. 1) was considered to process the TRS dala points. and the curve with the best fit was ohtained by iteration: $\mu_{\mathrm{f}}$ and $\mu^{\prime}$, are derived liom the curve (Fig. 3). Nolation in Eq. (I) is: $\phi(\rho, t)$, photon fluence rate: $S(\rho, t)$, photon source: $\rho$, radial position: $t$, time; $n$, index of relraction; $c$, speed of light in vacuum. Detailed description is given in the study by Cubeddu et al. (1994a).

$$
\frac{n}{\imath} \frac{\partial}{\partial t} \phi(\rho, t)-\left|3\left(\mu_{a}+\mu_{x}^{\prime}\right)\right|^{-1} \cdot \nabla^{2} \phi(\rho, t)+\mu_{a} \phi(\rho, t)=S(\rho, t)
$$




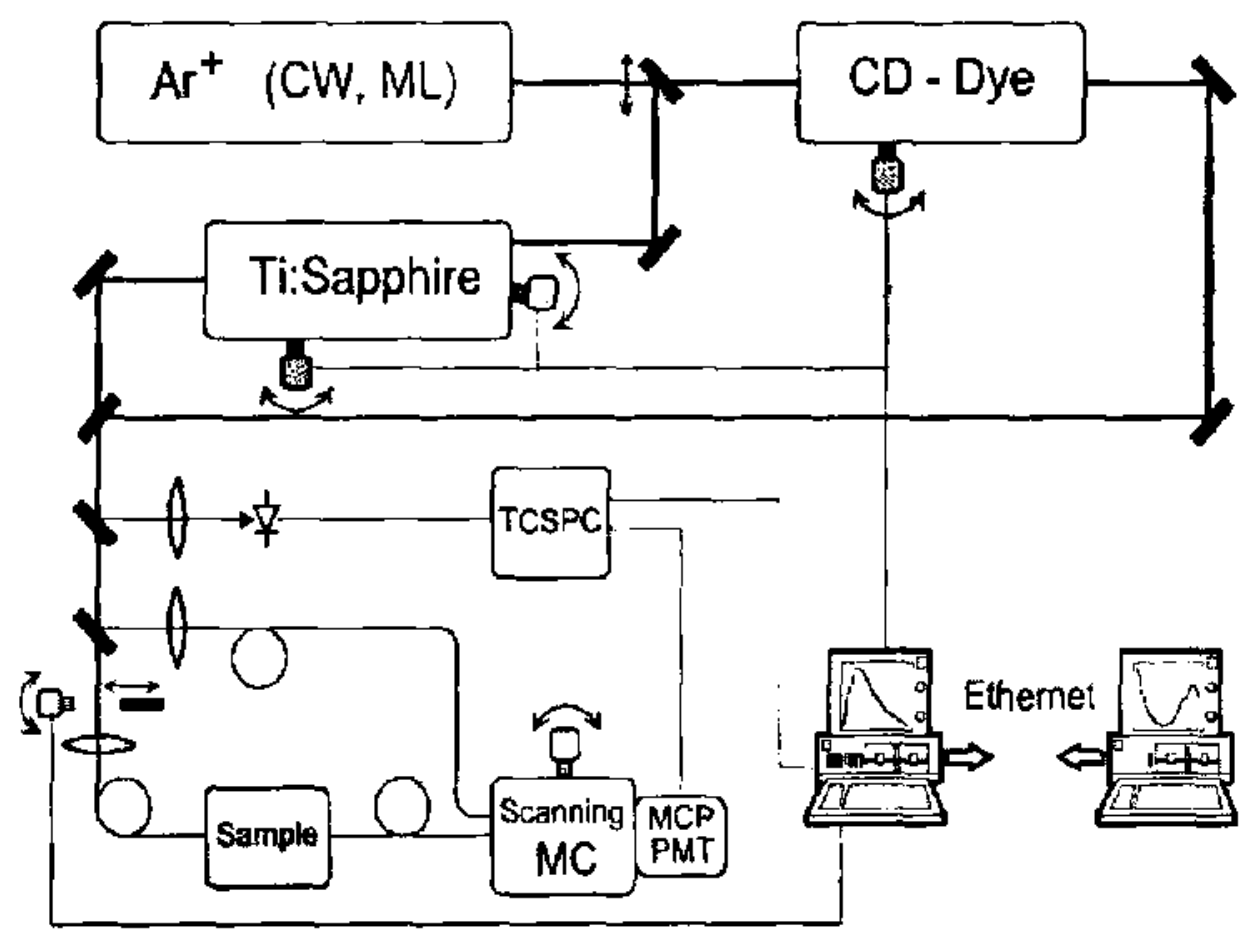

FIG. 1. SCHEME OF TIIE SYSTEM SET L:P HOR TRS MEASUREMENTS AT INFM LABORATORY: LINES INDICATE OPTICAL PATISS (FIRER OPTICS) FROM THIE LASERS IARGON. DYL AND TITANIUMMSAPPIIIRE) JIIROUGII 'TIIL SAMIPE AND TOWARDS TIE

DETECTOR (MUETICHIANNEL. PLATE PFIOTOMULTTPLIER, MCP PMT), CYTHER COMIONENTS: TIME-CORRELATLD SINGLE FIOTON COLNTING I'NI'T' ('TCSI'C), SCANNING MONOCROMATOK (MC) (CLIBEIJDUE ET AL. 1994A)

For this study, the absorption and transport scattering coefficients of both sides of each sample were registered at several wavelengths: 'ar-visihle $(672,750$ and $818 \mathrm{~mm}$ using diode lasers as light sources) and NIR (irom $900 \mathrm{to}$ $1000 \mathrm{~nm}$, at steps of $10 \mathrm{~nm}$ using a tunable laser). The nolation for these

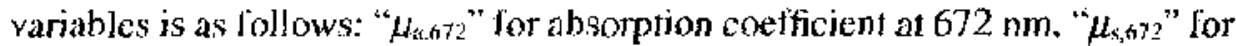
transport scattering coefficient at $672 \mathrm{~nm}$, and so on.

\section{Mechanical Measurements}

A confined eompression test was carried out for instrumental mealiness assessment. Using a texture analyzer (TA.XT2, Stable Micro Systems Lid, Surtey, UK) a maximum deformalion of $2.5 \mathrm{~mm}$ was applied at $20 \mathrm{~mm} / \mathrm{min}$ deformation rate on cylindrical probes of $1.7 \mathrm{~cm}$ height and diameter. Detormation was immediately removed at the same rate: two measurements were 


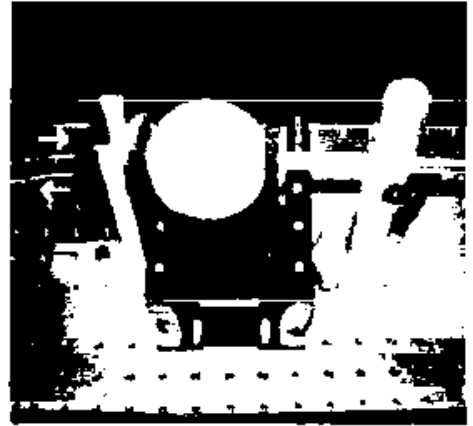

A

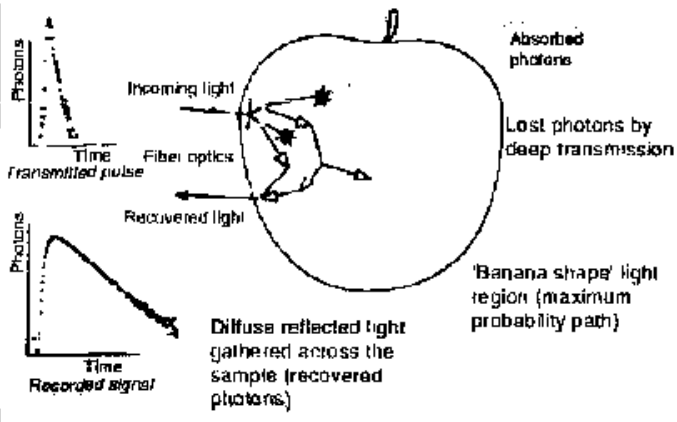

B

FIG. 2. SCHEME OF T'HE SAMPLE PRESENTATION FOR TRS MEASUREMEN'IS

(A) Itruit holder witl incoming liter and oulcoming liber (while arrows in phote) in contact with

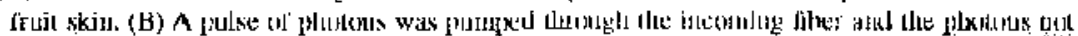
suffering absorption or deep tranimixsion were recovered.

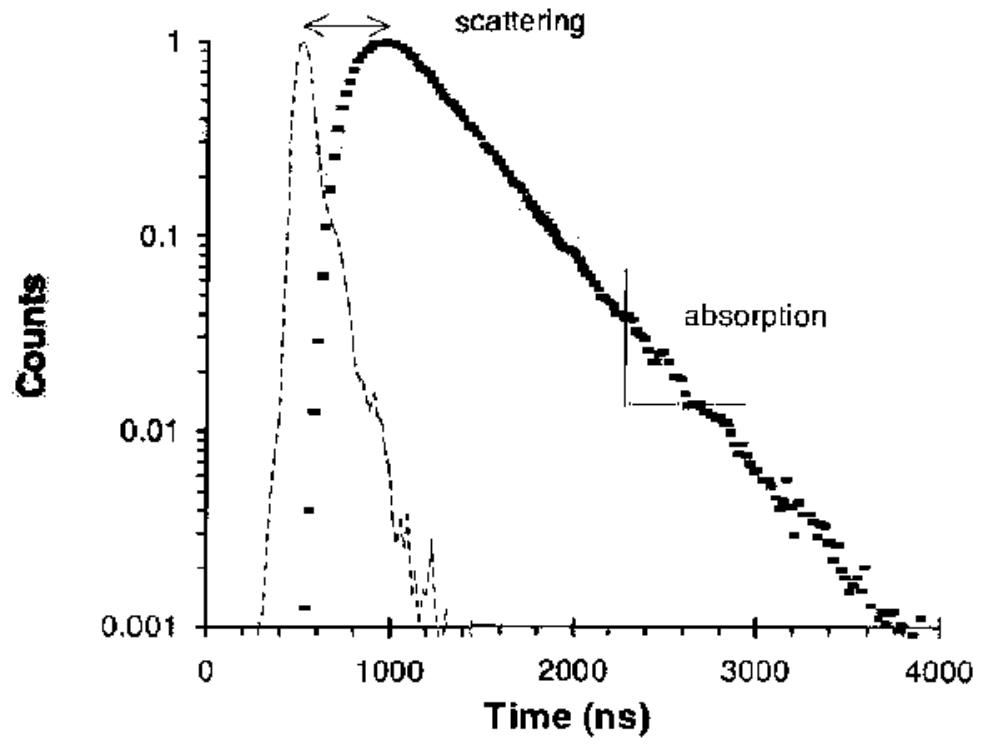

HIG. 3. TYPICA L DATA OITAINID) WITII TRS TECHINIQLE: IRIECTHD PULSE (NARROW PEAK) AND REMI'J'IEL PULSE (BKOADER CURVE, NORMALLEED TO TIIE PEAK

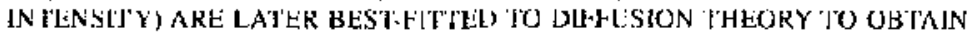
SCAITERING AND ABSORPTION COEFFICIFN'TS (CUBEDDL' ET AL. 1994A) 
made per fruil (one per side) using the average for the subsequent analyses tor this load/unload test. Cylinders were confined in a disk that had a hole of the probe sizc. The rod used for the compression test was $15.3 \mathrm{~mm}$ diameter to avoid any contact with the disk during testing. A filter paper (Albet $n^{\circ} 1305$ of $77.84 \mathrm{~g} / \mathrm{m}^{2}$ ) ahout the size of the disk was placed bencath the disk in order to recover the juice extracted dering the compression test. The area of the juice spol was measured later on using conventional image analysis equipment (Hitachi CCD black and white camera, Tokyo, Japan). The outline of the juice spot on the filter paper was extracted (Inage Pro Plus soltware, Media Cybernetics Silver Spring, MD) and the area inside it was used as indicalor of juiciness. The variables registered with this test and used in the statistical analyses (ahbreviations of the variables within brackets) are: hardness of the sample ( $S, " \mathrm{~N} / \mathrm{mm}$ ) expressed as the slope of the force-deformation curve during confined loading. and the juice area $\left(" J, " \mathrm{~mm}^{3}\right)$ recovered in the filter paper placed underneath the probe during the test.

Using the variables extracted from confined compression, the samples were labeled according to their instrumental mealiness stage, as a comhination of two possible hardness states (firm, not firm) with two possible juiciness states (juicy, nonjuicy). A sample was considered "not firm" when $S<20 \mathrm{~N} / \mathrm{mm}$, and "finm" otherwise. Besides it was labeled "nonjuicy" when $J<4 \mathrm{~cm}^{2}$, and "juicy" otherwise (Barreiro et al. 1998). Instrumental definition of mealiness requires a sample to be "not firm" and "nonjuicy" simultaneously (Table I).

\section{Statistical Analysis}

As a first stcp, linear corrclations between TRS variables, hardness and juiciness were analyzed. Because of the poor regression results (see Results section) and the fact that the aim was matching a categorical instrumental mealiness scale using TRS information, the statistical approach was switched to a classification algorithm.

Following an industry-oriented application for the TRS technique, a puss/fail classitication was searched for: Discriminant analysis technique was

TABLE I.

NDTATION OF FRLIT CATEGORILATIONS ACCORDINC IO 'IHE DESTRLCTIVE INSTRUMENTAL MEALINESS STATE: "FIRM" SAMPLE WHEN $S>20 \mathrm{~N} / \mathrm{mm}$ : "JUICY" SAMPLE IF $J>4 \mathrm{~cm}^{2}$. SAME GRAY TONE INDICATES MEMBERSIIP OF SAME GROUP

\begin{tabular}{|c|c|c|c|c|c|c|}
\hline & \multicolumn{2}{|l|}{ Two classes } & \multicolumn{2}{|l|}{ lhrec classes } & \multicolumn{2}{|c|}{ l'our classes } \\
\hline & Nonjuicy & Juicy & Nonjuicy & Juicy & Nonjuicy & Juicy \\
\hline $\begin{array}{l}\text { Nol firm! } \\
\text { Firm }\end{array}$ & $\begin{array}{l}\text { "Mealy" } \\
\text { "Nonmevily" }\end{array}$ & $\begin{array}{l}\text { "Nonmealy" } \\
\text { "Nonmealy" }\end{array}$ & $\begin{array}{l}\text { "Mealy" } \\
\text { "Nonmealy" }\end{array}$ & "Nonmealy" & $\begin{array}{l}\text { "Mealy" } \\
\text { "Dry" }\end{array}$ & "Soft" \\
\hline
\end{tabular}


used as the statistical tool used to create the classification models. Classificalion functions were buill with a stepwise approach, selecting or removing each variable by the analysis of the unique contribution of the respective variable to the discriminatory power of the model. The discriminatory ability of the models was evaluated either comparing the percentage of well-classified samples obtained with every model, or calculating the similarity index, $K$ (Eq. 7) used by Steinmetz ot al. (1996) as a measurement of the agreement between two instrumental classifications. $K$ calculation starts from a classification matrix that is converted into a probability matrix where $p_{i i}$ is the probability of a sample to be classified by nethed A and B into the same calegory $i$. The probabilities $p_{i j}$ (thiat method A classifies an object into category $i$ whereas method B classifies the same object into category $j$ ) are computed as staled in Eq. 2. Thus, $\theta_{1}\left(\mathrm{Eq}_{\mathrm{q}} .5\right)$ is the sum of coincident probabilities (along the main diagonal of the probability matrix: $p_{i i}$ ) and $\theta_{2}$ (Eq. 6) is the sum of the products of the accumulated probability of being in each row or column ( $p_{\text {it }}$ is the accumulated probability of being in row $i$, whereas $p_{+i}$ is the accumulated probability of being in column $j$, Lqs. 3 and 4).

$$
\begin{gathered}
p_{i j}=\frac{n_{i j}}{n} \\
p_{i+}=\sum_{i=1}^{q} p_{i j} \\
p_{t \cdot i}=\sum_{j=1}^{q} p_{j i} \\
\theta_{1}=\sum_{i=1}^{q} p_{i i} \\
\theta_{2}=\sum\left(p_{i+}\right)\left(p_{+i}\right) \\
K=\frac{\theta_{1}-\theta_{2}}{1-\theta_{2}}
\end{gathered}
$$

In this work the $K$ index is used to compare the destructive classification procedure with the nondestructive TRS method of classification. The advantage of using this similarity index is that, from the absolute proportion of cases where the methods agree $\left(\theta_{1}\right)$, it stibtracts the proportion of cases where the methods agree purely by chance $\left(\theta_{2}\right)$. 
Classification models were created first for the pooled database. joining both apple varictics. Varietal models were also created in a second phase. In all the cases, calibration of the classification models was performed using half of the samples for the discriminant analysis. Validation of the models was carried out with the test of the database.

For the creation of the classification models, in a first approach only two fruit states were used in order to create two-group classifications: "mealy" and "nonmealy." $A$ "mealy" sample was not firm and nonjuicy at the same time, whereas "nonmealy" samples gathered all the other possible combinations, in Unis first anaiysis.

Further approaches included classificalion models with samples classified into: (1) three stakes ("mealy" [nonjuicy and not firm], "nonmealy" [nonjuicy or not firm], "fresh" [juicy and firm]), and (2) four textural states ("mealy" [nonjuicy and not fim], "dry" but firm, "soft" hut juicy, "fresh" [ juicy and firmi]). Table I synthesizes the notation used for each combination of hardness and juiciness states, when creating two-group, three-group or four-group models.

\section{RESULTS}

\section{Linear Relation between Destructive and Nondestructive Variables}

Linear correlation between the variables extracted from the desiructive test (hardness and juiciness) and the nondestructive measurements (TRS ahsorption and scattering coefficients) was analyzed. In Fig. 4, a selection of TRS variables is presented in the form of a graphical correlation matrix. Correlation coefficients were low $(r<0.4)$ in any case. Internal correlation in the TRS dala (inside absorption spectra, scallering spectra, or between absorption and scattering coefficients) was high $(r=0.9)$ in most cases. Correlation was expected between absorption variables (as is normal within NIR spectra); however, correlation was nol expecled to be so high helween scattering and absorption paramelers, as they refer to dilferent physical phenomend.

\section{Destructive Classification of Samples according to Instrumental Mealiness}

Figure 5 shows the result of fruit classification into: firm. soft, dry and mealy. A higher number of mealy samples was oblained for Golden (22 out of 50) than for $\operatorname{Cox}(7$ oul of 40; Fig. 5). A wider range of texluse variation was found for Golden than lor Cox, in this case. Cox is a typical example of mealiness susceptible variety with very erratic mealiness onset, which is 


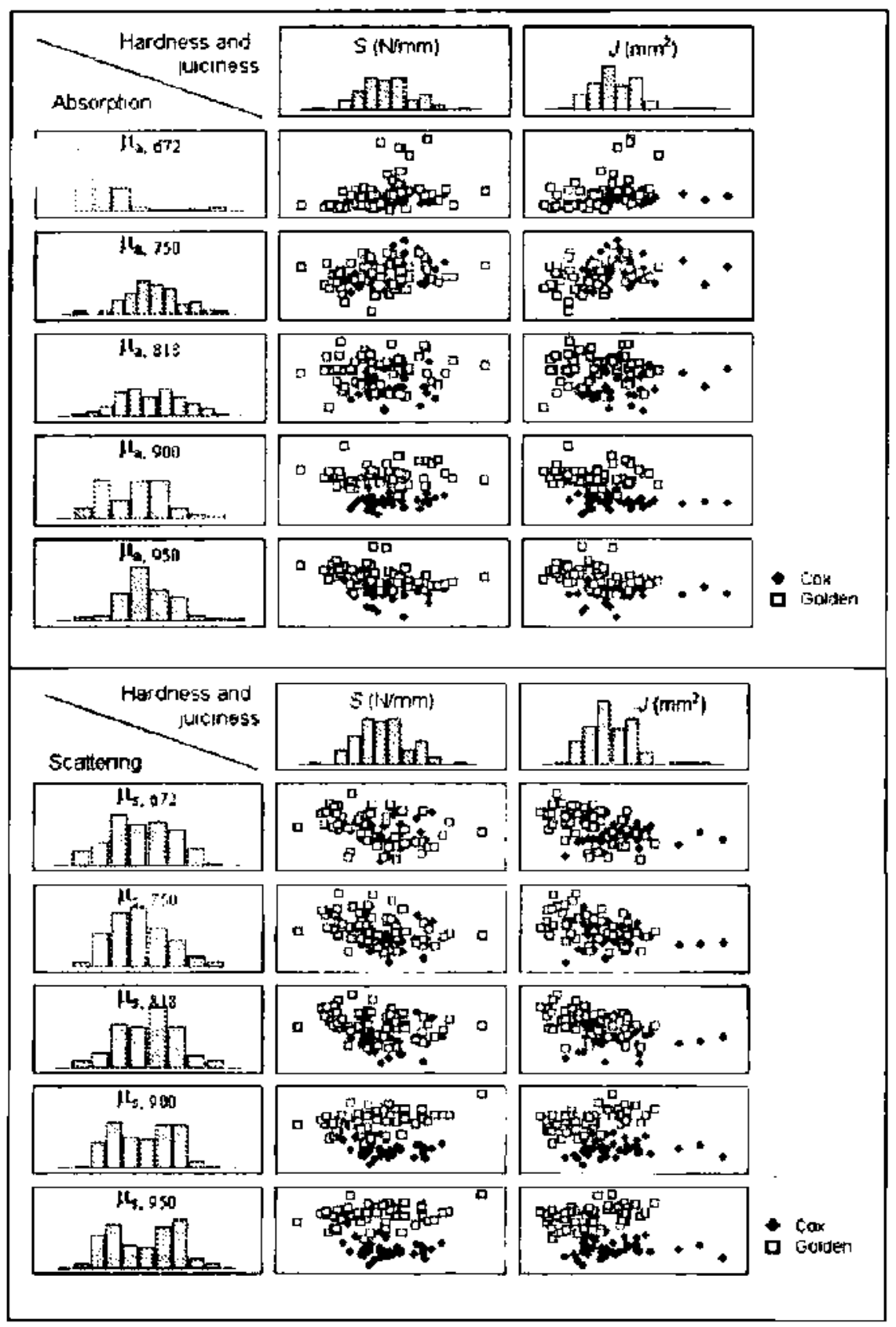

FIG, 4. IISTOGRAMS ANI) CORRLLATIONS BETWEEN SELECTED TRS VARIABLES

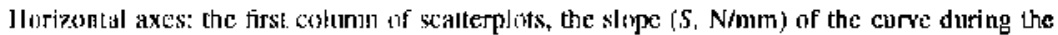
mechanical test is presented; the sccond column, the juicc aren recovered $\left(J\right.$, mm $\left.{ }^{2}\right\rangle$. Vertical axes: absorption and transport scattering l'kS' coefficients, al several wavelenghth. 


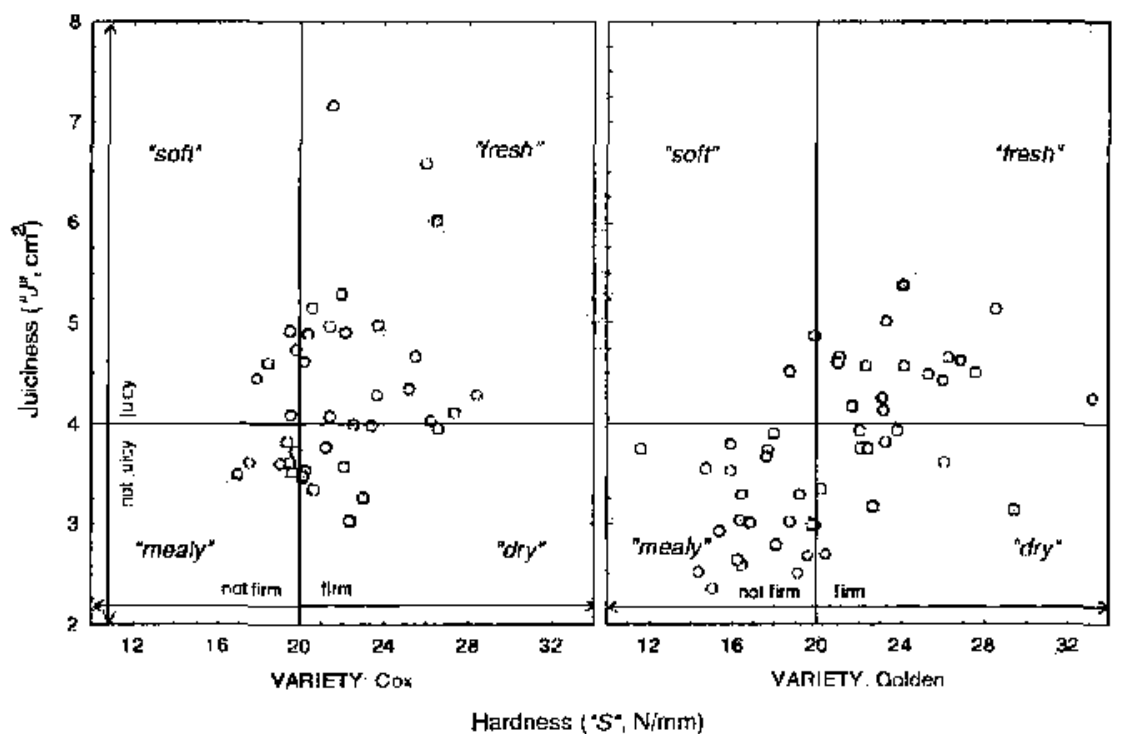

FIG. 5. HARDNESS VERSLS JUICINESS OF TESTED AJPLES: LINES INDICATE DISCRIMINATING LIMITS JOR "DKY" TEXT"IRAL CATFGORY (JLICINESS < 4 $\mathrm{cr}^{2}$ ), "SOFT" (HARDNESS < $20 \mathrm{~N} / \mathrm{mm}$ ) AND THE COMBINATION OH BOTH ("MEALY")

confirmed in this case. Textural disorder in batches being dry and soft for Cox lacks from a comparable cell disaggregation stalus.

\section{Models to Classily Nondestructively Samples Using TRS}

Discriminant analysis functions wete huilt using selected TRS coeffi-

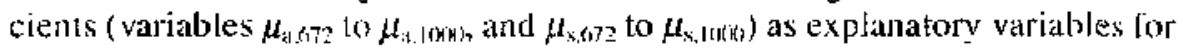
the classificition of samples ino (Table 1): (1) two textural categories ("mealy" versus "nonmealy"), (2) three textural calcgorics ("mealy" "nonmealy," "fresh"), or (3) four textural categories ("mealy." "dry," "sofl," "fresh"). The number of individuals in each slage was not homogenenus and patial classification scores obtained for each category were uneven: thus the global score of well-classified samples in every model is a wejghed average, proportional to group sizes.

A first model was calibrated using half of the pooled data of both varieties for the discrimination between "mealy" and "nonmealy" slates. Fifleen TRS variatles were used in the nodel achieving a percentage of correctly classified individual fruits of $98 \%$. Validation with the rest of the database (Table 2) resulted in $80 \%$ of the samples correctly classified. More misclassifications 
TABLE 2.

VALIDATION CLASSIFICATION MATRLX FOR APPLES

(COX AND GOLDEN) AS "MEAIY" OR "NONMEAI.Y" LSING 15 TRS VARIABLES AND HALF OH THIE DATABASE. GRAYED AREAS DENOTE CORRECY CLASSIFICATIONS. ROWS: OBSHRVEI) BY MECIIANICAL MLASLREMIEN'SS. COLUMNS: PREDICTED BY TRS

\begin{tabular}{lccl}
\hline & Nonrutaly & Mealy & \% Correct \\
\hline Nonmealy & 26 & 6 & 82 \\
Mealy & 3 & 10 & 77 \\
Jistal & 29 & 16 & 80 \\
\hline
\end{tabular}

TABLE 3

VALIDATION CLASSIFICATION MATRIX FOR APPLES (COX AND GOLDEN') AS "MEALY." "NONMEALY" OR "FRESH."' GRAYEO AREAS DENO'TE CORRECT" CLASEIFICATIONS. ROWS: OBSERVEII BY MFCIIANICAI MEASLREMENTS. COLUMNS: I'REDICTED BY TRS

\begin{tabular}{lcccl}
\hline & Fresh & Nonmealy & Mcaly & $\%$ Correct \\
\hline Fresh & 9 & 5 & 3 & 53 \\
Nonfrealy & 2 & 7 & 6 & 47 \\
Mcaly & 2 & 4 & 7 & 54 \\
Total & 13 & 16 & 16 & 51 \\
\hline
\end{tabular}

were proportionally obtained for mealy samples incorrecly predicted as fresh ( $1 / 15$ in the calibration and $3 / 10$ in the vaiddation, lack of sensitivity), than the opposite case $(0 / 29$ and $6 / 26$, lack of specificity).

The 15 variables in the classification fitnctions were mostly absorption coefficients and some scattering coefficients, at wavelengths around the chlorophyll absoption peak $(670 \mathrm{~nm})$ and a wide range of NIR wavelengths $(818$, $900,930,940,960$ and $980 \mathrm{~nm}$ ).

When trying to estimate three texture stages ("Iresh," "nonmealy" and "mealy") with TRS. the performance of the new models decreased considerably lrom $981071 \%$. Moreover, validation only achieved $51 \%$ (Table 3). The estimation of four textural stages ("fresh," "dry," "soft" and "mealy") achieved $71 \%$ in the calibration model. but only $47 \%$ in the validation (Table 4). In both cases it was noticed that the "mealy" category was best predicled than the other groups ("fresh," "dry." "soft" or the combination of them, i.e., "nonmealy").

In order to reduce the number of variables in the models to enhance robustness, new analyses were performed with more restrictive conditions in the number of wavelengths and the tolerance level of the stepwise method. It 
TABLE 4.

VALIDATION CLASSIFICATION MATRIX FOR APPLES

(COX AND (OOLIOEN) AS "MEALY," "SOFT", "DRY" OR

"FRESUI" GRAYED AREAS DENOTE CORKECT

CLASSIFICATYONS. ROWS: OBSERVED BY MECIIANICAL MEASLREMENTS, COLUMNS: PREDICI'ED BY TRS

\begin{tabular}{lccccc}
\hline & Hresh & Sof & Dry & Mcaly & \% Correct \\
\hline Eresh & 17 & 1 & 5 & 4 & 63 \\
Soft & 1 & 1 & 3 & 0 & 50 \\
Bry & 2 & 0 & 3 & 5 & 64 \\
Mealy & 1 & 1 & 1 & 10 & 86 \\
Total & 11 & 3 & 12 & 19 & 47 \\
\hline
\end{tabular}

TABLE 5.

VALIDATION: CLASSIFICAFION MATRIX FOR APPLES

(COX AND GOLUEN) AS "MEALY" OR "NONMEALY" USING HIVE TRS VARIABLES. GRAYED AREAS DENOTE CORRICT CLAASSIF'ICATIONS. ROWS: OLSERVED BY MECIIANICAL MEASUREMENTS. COLUMNS: PREDICTED BY TRS

\begin{tabular}{llll}
\hline & Nonmealy & Mealy & \% Correct \\
\hline Nonrnealy & 22 & 10 & 69 \\
Mealy & 3 & 10 & 77 \\
Total & 25 & 20 & 71 \\
\hline
\end{tabular}

was seen that all the remaining variables in the models were absorption coefficients, and all the scattering ones were removed in the stepwise algorithm. The remaining wavelenglhs were around the $670 \mathrm{~nm}$ peak also combined with the $960-980 \mathrm{~nm}$ NIR region. Overall segregation ahility in the estimation of two textural stages with five TRS variables and with three TRS variables were, respectively, $89 \%$ and $82 \%$, with validations achieving $71 \%$ (Table 5) and $88 \%$ (Table 6).

Separate models were also built for each variety, to assess mealiness onset ("nonmealy" versus "mealy"). In the case of Cox apples the classification score reached $100 \%$ whereas lor Golden apples the score dropped to 92\%. Validations showed $80 \%$ of well-classified fruits for Cox and $68 \%$ for Golden (Table 7).

Table 8 shows the evaluation of models in terms of similarity index (" $K$ " $\%)$. The subtraction of random agreement between procedures leads to poorer scores with respect to the pereentage of well-classified individuals. The best 
TABLE 8 .

CLASSIFICAIION PERFORMANCE OF THE MODELS. COMPARING THE NUMBER OF CORRECTLY CLASSIFLED FRUITS (CC) WITH THE SIMLARITY INDEX $(K)$. AND ITS COMPONENTS: $\theta_{1}$ (ABSOLIJT, PROPORTION OF CASES WHFRE THE DESTRUCTIVE AND TRS CLASSIFICATIONS AGREE) AND $\theta_{2}$ (PROPORTION OF CASES WHERE THEY AGREE PURELY BY CHANCE)

\begin{tabular}{|c|c|c|c|c|c|c|c|}
\hline & Mexdel & CC (calibration) (\%) & $C C$ (validation) (\%) & $K(\%)$ & $K-\mathrm{CC}(*)$ & $\theta_{1}$ & $\theta_{2}$ \\
\hline 1 & $\begin{array}{l}90 \text { apples (Cox and Golden) as "mealy" or } \\
\text { "nomealy" using } 15 \text { TRS variables }\end{array}$ & 98 & 80 & 54 & -26 & 0.8000 & 0.5609 \\
\hline 2 & $\begin{array}{l}40 \text { apples (Cox and Golden) as "mealy" or } \\
\text { "nommealy" using five TRS variabies }\end{array}$ & 89 & 71 & 39 & -32 & 0.7111 & 0.5234 \\
\hline 3 & $\begin{array}{l}90 \text { apples (Cox and Golden) as "mealy" or } \\
\text { "nonmealy" using three TRS variables }\end{array}$ & 82 & BB & 73 & -15 & 0.8888 & 0.5797 \\
\hline 4 & $\begin{array}{l}\text { 50 Goldet apples as "mealy" or } \\
\text { "nonmealy" using seven TRS varidbles }\end{array}$ & 92 & 68 & 33 & -35 & 0.6800 & 0.5200 \\
\hline$s$ & $\begin{array}{l}40 \text { Cox apples as "mealy" or "nonmealy" } \\
\text { using seven TRS variables }\end{array}$ & 100 & 80 & 54 & -26 & 0.8000 & 0.5609 \\
\hline 6 & $\begin{array}{l}90 \text { apples (Crox and Givlden) as "mealy." } \\
\text { "nonmealy" or "fresh" using seyen TRS } \\
\text { variables }\end{array}$ & 71 & 51 & 27 & -24 & 0.5111 & 0.3303 \\
\hline 7 & $\begin{array}{l}90 \text { apples (Cox and Golden' as "mealy," } \\
\text { "soft," "dry" or "fresh" using seven TRS } \\
\text { variables }\end{array}$ & 71 & 47 & 25 & -22 & 0.4666 & 0.2809 \\
\hline
\end{tabular}


TABI,E 6.

CLASSIFICATION MAIRIX FOR APPLES (COX AND)

GOLDEN) $\triangle S$ "ME $A L Y "$ "OK "NONMEALY" USING THREE

TKS VARIABLES. CRAYEI AKEAS DENOTE COKKECT

CLASSIFICATIONS. ROWS: OBSERVEU BY MECHANICAL MEASLREMENTS. COLLMNS: PREDICTED BY TRS

\begin{tabular}{lrrr}
\hline & Nommealy & Mealy & \% Correc \\
\hline Nonmcaly & 29 & 3 & 51 \\
Mitaly & 2 & 11 & 85 \\
Total & 31 & 14 & 88 \\
\hline
\end{tabular}

TABLE 7.

CLASSIFICATHON MATKICES FOK GOLUEN APPLES

(UPPER PART) ANU COX APPLES (LOWER I'ART) AS

"MEALY" OR "NONMEALY" LSING SEVEN TRS

VARIABLES GIRAYFI AREAS DENOTE CORRECT

CLASSIHICATIONS. ROWS: OBSERVED. COLUMNS:

HREDIC'TED

\begin{tabular}{|c|c|c|c|}
\hline & Nonmcaly & Meaty & "\% Correct \\
\hline \multicolumn{4}{|l|}{ Golken } \\
\hline Nonmeaty & 11 & $A$ & 73 \\
\hline Mealy & 4 & 6 & 60 \\
\hline Total & 15 & 10 & 68 \\
\hline \multicolumn{4}{|l|}{$\operatorname{Cox}$} \\
\hline Nixumealy & 14 & 3 & 82 \\
\hline Mealy & 1 & 2 & 67 \\
\hline Thial & 15 & 5 & 80 \\
\hline
\end{tabular}

result corresponds to model 3 with a decrease of $15 \%$. This model uses only three TRS parameters, which is a premise for less overfitting and better robust ness.

\section{DISCUSSION}

As it has been observed in other studies (Barreiro ef al. 1998; Andani ef al. 1999), the process for obtaining mealy samples to carry out research is not always a straightforward rouline. The Cox samples stored under strict relative humidity and temperature conditions to promote mealiness development, not always show at the end of the treatment a mealy stage. In fact, a low percentage of them were found mealy using the instrumental destructive test. 
This may indicate that there are more factors affecting mealiness than just the humidily and temperature during storage, harvest date and variety. On the other hand, it seems clear that late harvested Golden apples can develop textural disorders by themselves and already "in the tree," without shelf life. This is of high importance for apple growers when, because of climatic conditions or labor problems, it is impossible to pick the whole production on time, leaving part of it on the orchard.

The predictive models that estimatc two instrumental mealiness stales ("nonmealy," "mealy") using absorption and scattering TRS cosfficients show high discrimination performance when classilying samples from both apple varieties ( $80 \%$ of well-classified fruts in the validation; 15 variables used in the model). The robustness in the validation process should be erthanced, both using more samples and reducing the number of variables.

Models estimating more than iwo textural states ofter lower segregation abilities. The prediction of three and four states shows, in both cases, a score of $71 \%$ of well-classified fruits. with very poor validation results $(51 \%$ and $47 \%$ of well-classified fruits, respectively). The fact that the highest misclassification scores were found in the groups other than "mealy" suggests that the use of the TRS technique itself is not adequate to detect the individual quality parameters involved in the development of mealiness (apparent drough of lissues, soltening). It can be also a problem of the system sel up or just at malter of detection resolution.

The allempt to reduce the number of variables in the models was satisfactory. Pertormance in the detection of mealiness onset "nonmealy," "mealy") was enhanced from 80 to $88 \%$ using three variables, when the validation scores are compared. This fact confirms the increase in rohusiness for lower number of variables and the risk that is commonly assumed when using global models.

Given the differences in mealiness Irealments among the varieties, the results of the classification modets applied to the pooled datta from both of them, show that a real cause-effect may be detected by this technique, related to the "loss ol" tightness in the tissues" and "dryness" associated to mealiness. The development of separate models for the varieties is a logical slep ahead in the process, and the first attempts show different results for the two of them. In the case of Cox the classification is the best: in the case of Golden the model is unable to obtain a belter score than the pooled data. Thesc varietal models were created wilh a reduced number of rruits, and at the same time many variables are used (seven), which decreases the confidence on their robustness.

The similarity index $(K)$ is useful 10 estimate the robustness of the models in terms of real segregation capacity, as it eliminates the effect of "agreement hy chance." In the models presented in this work, $K$ index punishes the performance of the models by nearly $20-30 \%$ in many cases. This indicates 
that: (1) the destructive guantification of instumental mealiness is not measuring exaclly the same property as TRS. because the agteement between bouh methods is only 70\%; and (2) the model may be unstable or nol repeatable enough for industrial usage. The applicability of the present models on an industrial basis (i.e., a sensor on a packing line) has to be improved, either with better molels or with at complementary sensor logether with sensor fusion decision algorithms.

\section{CONCLUSIONS}

Time-resolved reflectance spectroscopy has been proven to be a tseful technique to identify mealiness in apples nondestructively. Error rates in classification models discriminating mealy samples from nonmealy ones are Iow, when considering the traditional indicator of the scgregation ability (percontage of correctly classificd fiuits). The segregation hetween more than two texlural stages of mealiness (other than "nonmealy" and "mealy") cannol he achieved to date. A TRS prototype to detect mealiness should be developed tor on-line measurements, and sufficient data should be gathered to tune the models. The technique. new in the field of food sensors, shows interesting polential for internal parameter detection of quality allributes and disorders.

\section{ACKNOWLEDGMENTS}

The authors acknowledge Dr Veerle De Smedt, from the Katholieke Unjversiteil I_euven (Belgium), for the Cox apples, picked and treated al their facilities. Also we thank Carlos Gil, from Agro21 S.A. (La Almunia de Da Godina, Spain), for the Golden apples and his expertise knowledge. Finally, we acknowledge the EC for liAIR CT96-1060 project funding and the Comunidad de Madrid for the PhD (FPl) grant to the first author.

\section{REFERENCES}

ABBOTT, J.A. 1999. Quality measurement of fruits and vegetables. Postharvesi Biol. Technul. 15, 207-225.

AHRENS, M. and HUBER, D. 1987. A Method for Measuring Mealiness in Tomato Fruit. Vegetable Crops Departmeni, Universily of Florida, Gainesville, FL, 32611 .

ANDANI, Z., DE SMEDT, V. and NICOLAÏ, B.M. 1999. Development of mealiness in apples under shelf-life conditions. Food Sci. Technol. Today $4(13), 203-204$. 
BARREIRO, P., ORTIZ, C., RUIZ AITISENT, M., DE SMEDT, V., SCHOTTE, S., BHANJI, Z., WAKELING, I. and BEYTS, P.K. 1998. Comparison hetween sensorial and insirumental measurements for mealiness assessment in apples. $\Lambda$ Collaborative Test. J. 'Texture Studies 29 , $509-525$.

BARKFIRO, P., RULZ-CABLILLO, J., FHRNÁNDHZ-VALLE, M.F., ORTIZ, C. and RUIZ-ALTISENT, M. 1999. Mediness assessment in apples using MRl techniques. Magn. Reson. Imag. 17, 275-281.

BECHAR, A., MIZRACH, A., BARRLIRO, P. and LANDAHL, S. 2005. Determination of mealiness in apples using ultrasonic measurements. Biosyst. Eng. 91, 329-334.

BIGNAMI, C., SCOSSA, A. and VAGNONI, G. 2003. Evaluation of old Italian apple cultivars by means of sensory analysis. Acta Hort. (ISHS) $598,85-90$.

CUBEDDU, R., MUSOLINO, M., PIFFERI, A., TARONI, P. and VALENTINI. G. 1994a. Time-resolved reflectance: A systematic study for application to the optical characterization of tissues. IEEE. J. Quantum Elect. 30), 242I-2430.

CUBEDDU, R., MUSOLINO, M., PIFFERL, $\Lambda$., TARONI, P., VALENTINI, G. and CANTI, G. 1994b. Absorption spectrum of hematoporphirin derivative in vivo in a murine iumor model. Photochem. Photobiol. 60, 582-585.

CUBEDDU, R., PIFFERI, A., TARONI, P., TORRICELLI, A., VALENTINI, G., DOVIER, C., JOHNSON, D., RUIZ-ALTISENT, M. and VALERO, C. 2001 a. Non-destructive quantification of chemical and physical properlies of fruits by time-resolved reflectance spectroscopy in the waveiength range 650-1000 $\mathrm{nm}$. Appl. Opl. 40, 538-54.3.

CUBEDDU, R., PIFFERI, A., TARONI, P.. TORRICELLI, A., VALENTINI, G., RUIZ-ALTISENT, M., VALERO, C., ORTIZ, C., DOVER, C. and IOHNSON. D. 200lh. Time:-resolved reflectance spectroscopy applied to the non-destructive monitoring of the internal optical properties in apples. Appl. Spectrose. 55, 1368-1374.

DE SMEIT, V. 2000. Measurement and modelling of mealiness in apples. PhD Dissertation Thesis. Katholieke Universiteil Leuven, Leuven, Beigiurn.

DE SMEDT, V., PAUWELS, E., DE BAFRDEMAEKER, J. and NICOLAÏ, B.M. 1998. Microscopic observation of mealiness in apples: A quantitative apjproach. Postharvest Biol. Technol, 14.151-158.

FISHER, D.V. 1943. Mealiness and quality of delicious apples affected by growing conditions, maturity and storage techniques. Sci. Agric. 23, 569-588. 
GROSS, K.C. and SAMS. C.E. 1984. Changes in cell wall neutral sugar composition during fruit ripening: A species survey. Phy lochemistry 23, 2457-2461.

HARKER, F.R. and HALLETT, I.C. 1992. Physiological changes associated with development of mealiness of apple during storage. HortScience 27. $1291-1294$.

HARKER, F.R., STEC, M.G.H., HALLET, I.C. and BENETT, C.L. 1997. Texture of parenchymatous plant tissue; A comparison between tensile and oher instrumental aud sensory measurements ol tissue sirength and juiciness. Postharvest Biol. Technol. 11, 63-72.

ORTIZ, C., BARREIRO, P., RUIZ-ALTISENT, M. and RIQUELME, F. 1999. An identification procedure of woolly soft-ftesh peaches (cv. Maycrest) by instrumental assessment. J. Agric. Eng. Res. 76, 355-362.

ORTIZ, C., BARREIRO, P., CORREA, L., RUIZ-ALTISEN'l, M. and RIQUELME, I. 2001. Non-destructive identification of woolly peaches using mechanical impact response and NJR spectroscopy. J. Agric. Eng. Res. 78, 281-289.

PAOLET'II, F., MONETA, E. and SINESIO, F. 1993. Mechanical properties and sensory evaluation of selected apple culitivars. Lebensm.-Wiss. Technol. 26, 264-270.

SONEGO, L., BEN-ARIE, R., RAYNAL, J. and PECH, J.C. 1995. Biochemical and physical evaluation of textural characteristics of nectarines exhibiling woolly breakdown: NMR imaging, $X$-ray computed tomography and pectin composition. Postharvest Biol. Technol. 5, 187-198.

STEINMETZ, V., CROCHON, M., BELLON-MAUREL, V., GARCÍA FERNÁNDEZ, J.L., BARREIRO, P. and VERSTREKEN, L. 1996. Sensors for fruit firmness assessment: Comparison and fusion. J. Agric. Eng. Res. 64, 15-18.

VALERO, C., RUIZ-ALTISENT, M., CUBEDDU, R., PIFFERI, A., TARONI, P., TORRICELLI, A., VALENTINI, G., JOHNSON, D. and DOVER, C. 2004a. Selection models for the intermal quality of fruit, based on time domain laser reflectance spectroscopy. Biosyst. Eng. 88, $313-323$.

VALERO, C., RUIZ-ALTISENT, M., CUBEDDU, R., PIFFERI, A., TARONI, P., TORRICELLI, A., VALENTINI, G., JOHNSON, D, and DOVER, C. 2004b. Detection of internal quality in kiwi with timedonlain diffuse reflectance spectroscopy. Appl. Eng. Agric. 20, 223-230. VERLINDEN, B.E., NICOLAÏ, B.M. and DE BAERDEMAEKER, J. 1997. Modelling the relation between macmscopic vegetable tissue strength and the strength of cell walls and middle famellae: A stochastic approarh. ASAE Paper 976025. 
VON MOLLENDORF, L.J., JACOBS, G, and VILLIERS, O.T. 1992. Postharvest factors involved in the development of chilling injuries in peaches and neclarines. J. S. A[r. Soc. Hortic. Sci. 5, 58-66.

VON MOLLENDORF, L.J., VILLIERS, O.T., JACOBS, G. and WESTRAAD, I. 1993. Molecular characteristics of pectic constituents in relation to firmness, extractahle juice, and woolliness in nectarines. J. Am. Soc. Hortic. Sci. $/ 78,77-80$. 